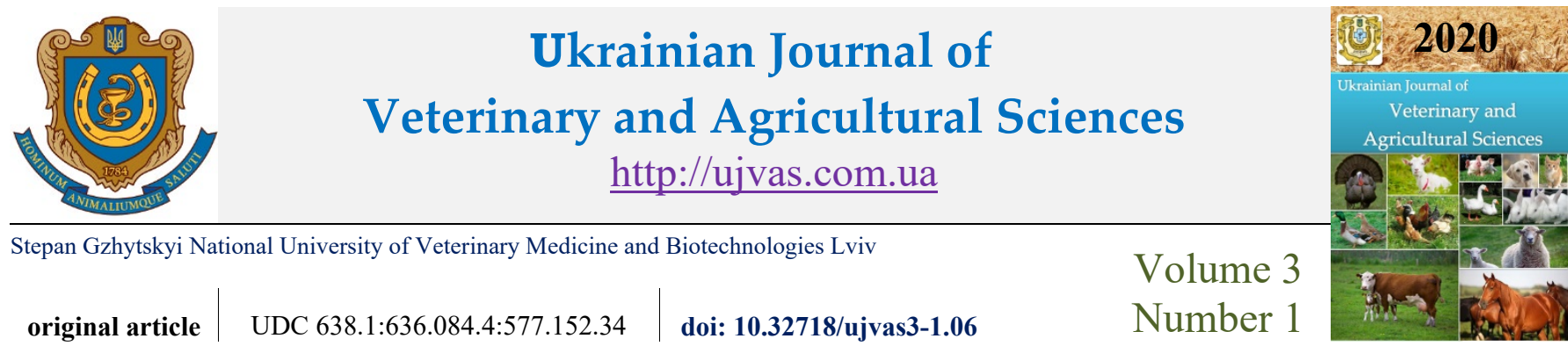

\title{
The effectiveness of using protein mixed feed in feeding honey bees
}

\author{
V. M. Nedashkivskyi ${ }^{1}$, H. V. Hutsol ${ }^{2}$ \\ ${ }^{1}$ Bila Tserkva National Agrarian University, Soborna pl. 8/1, Bila Tserkva, 09117, Ukraine \\ ${ }^{2}$ Vinnytsia National Agrarian University, Sunny str., 3, Vinnytsia, 21008, Ukraine
}

\begin{tabular}{|c|}
\hline $\begin{array}{l}\text { Article info } \\
\text { Received } 03.01 .2020 \\
\text { Received in revised form } \\
\quad 04.03 .2020 \\
\text { Accepted } 05.03 .2020\end{array}$ \\
\hline $\begin{array}{l}\text { Correspondence author } \\
\text { Volodymyr Nedashkivskyi } \\
\text { Tel: +38-097-153-30-53 } \\
\text { E-mail: profkom1967@ukr.net }\end{array}$ \\
\hline $\begin{array}{l}2020 \text { Nedashkivskyi V. et al. This is } \\
\text { an open-access article distributed } \\
\text { under the terms of the Creative } \\
\text { Commons Attribution License, } \\
\text { which permits unrestricted use, } \\
\text { distribution, and reproduction in any } \\
\text { medium, provided the original } \\
\text { author and source are credited. }\end{array}$ \\
\hline$(\mathrm{cc}) \mathrm{BY}^{\mathrm{B}}$ \\
\hline
\end{tabular}

Contents

1. Introduction

2. Materials and methods ......... 35

3. Results and discussion ...... 35

4. Conclusions ............... 36

References .................... 36

\begin{abstract}
The study of effectiveness of the use of protein feeding bees was carried out in the conditions of the apiary ALLC "Volodymyr" in village Shershni Tyvriv district of Vinnytsia oblast. According to the principle of analogous groups were selected bee colonies for the formation of experimental groups. Protein feed was moistened with 50\% sugar syrup and filled in the honeycomb. According to the experimental scheme during the preparatory period the bee colonies of the experimental groups II, III and IV were fed a feed mixture in an amount of $25 \mathrm{~g}$ per day. According to the experimental scheme during the main period bee colonies were fed a feed mixture of $70 \mathrm{~g}$ per day. Accounting of bees brood on the set dates was carried out at the expense of a grid frame every 12 days. Commercial honey was determined by weighing after pumping from each bee colonies separately. Forage honey was determined by weighing the honeycomb and then subtracting the conditional mass of the honeycomb. During the experimental Ukrainian breed bee colonies were involved which they were kept in long hive. Care and maintenance for bee colonies were the same. It was studied the effectiveness of using combined protein feeds in bee feeding. It is proved that in the spring during the harvesting honey use protein feeds (defatted soya flour with soy peptides and pollen) for feeding bees has a positive effect on the brood rearing by bee colonies and the production of honey and wax in the following sequence: defatted soya flour and pollen $(50 \%+50 \%)$ defatted soya flour and soy peptides $(50 \%+50 \%)$ defatted soya flour $(100 \%)$.
\end{abstract}

Key words: beekeeping, nectariferous plant, defatted soya flour, soy peptides, comb capping, comb foundation, brood rearing.

\section{Citation:}

Nedashkivskyi, V. M., \& Hutsol, H. V. (2020). The effectiveness of using protein mixed feed in feeding honey bees. Ukrainian Journal of Veterinary and Agricultural Sciences, 3(1), 34-37.

\section{Introduction}

In Ukraine beekeeping is one of the leading branches of animal husbandry. During the last period of formation of agricultural production, a significant number of industries have limited their production capacity due to a significant reduction of resources. Despite the critical situation in the agricultural sector, the beekeeping industry not only hasn't reduced its capacity but on the contrary increased the gross production of medicinal and high-performance products. Although mainly at the expense of the private sector (Taranov, 1987; Polishhuk, \& Gajdar, 2008; Drujbiak et al., 2017; Vishchur et al., 2019).

However, today the beekeeping industry is affected from negative natural and climatic factors a high level of chemicalization and institutional economic uncertainty (Ponomar'ova, 1980; Lazarjeva et al., 2017; Jefimenko, 2018).

An increase in the ambient temperature on the background of reduced precipitation, an uncontrolled decrease in nectariferous plant in the conditions of forest lands, chemical protection from pests and weeds of plants and the lack of State protection in the field of beekeeping significantly inhibit its development (Polishhuk, 1975; Razanov et al., 2010; Kosicyn, 2012; Kovalskyi et al., 2018). One of the most significant factors that affects the livelihoods bees and making their products is providing them with sufficient feed (Taranov, 1986; Vishchur et al., 2016; Gucol et al., 2017; Kovalchuk et al., 2019). Therefore, it is known that during the year one bee colony consumes up to $80 \mathrm{~kg}$ of carbohydrate and up to $20 \mathrm{~kg}$ of protein feed. Insufficient provision of carbohydrate and protein feed to bees negatively affects on their livelihoods and on the amount of products produced. In particular, under these conditions there is a decrease in the development of bee colonies which leads to a decrease in their production of honey, wax, bee pollen, bee bread, royal jelly and another products. At the same time, it is necessary to note the significant departure as bees and bee colonies in winter and the low pollination efficiency (Fedoruk \& Romaniv, 2013; Jagich \& Losjev, 2020). As a 
result the economic efficiency of the beekeeping industry is reduced. It is known that the level feed supply of bee is largely depends on the capacity of the honey-bearing base (Kosicyn, 2010). In the forest-steppe the honey-bearing base is characterized by one that it is incomplete provide bees feed due to the high ploughing of land up to $80 \%$, especially in the early spring and autumn periods (Komisar, 2005; Jefimenko, 2018).

Consequently, in early spring and at the end of the summer period the intensity of providing bees with highquality feed is reduced which delays the development of bee families, reduces their productivity and economic efficiency (Verygin, 2010).

Under these conditions, there is a need to restore bee feed stocks with various substitutes for flower feed (Taranov, 1986; Polishhuk, \& Gajdar, 2008; Dobrovs'k, 2017).

Table 1

Research Scheme

\section{Materials and methods}

The study of effectiveness of the use of protein feeding bees was carried out in the conditions of the apiary ALLC "Volodymyr" in village Shershni Tyvriv district of Vinnytsia oblast.

According to the principle of analogous groups were selected bee colonies for the formation of experimental groups.

During the experimental Ukrainian breed bee colonies were involved which they were kept in long hive. Care and maintenance for bee colonies were the same.

The experimental was carried out according to the scheme shown in table 1.

\begin{tabular}{|c|c|c|c|c|c|}
\hline \multirow[b]{2}{*}{$\begin{array}{l}\text { The experimental } \\
\text { groups of bee colonies }\end{array}$} & \multirow{2}{*}{$\begin{array}{c}\text { Number of bees } \\
\text { colonies in a } \\
\text { group }\end{array}$} & \multicolumn{2}{|c|}{ Features of the period of preparation } & \multicolumn{2}{|c|}{ Features of the main period } \\
\hline & & $\begin{array}{l}\text { duration, } \\
\text { days }\end{array}$ & feed ingredients & $\begin{array}{l}\text { duration, } \\
\text { days }\end{array}$ & feed ingredients \\
\hline I control group & 10 & 6 & without feeding & 10 & without feeding \\
\hline II experimental group & 10 & 6 & $100 \%$ defatted soya flour & 10 & $100 \%$ defatted soya flour \\
\hline III experimental group & 10 & 6 & $\begin{array}{c}50 \% \text { defatted soya flour }+ \\
50 \% \text { soy peptides }\end{array}$ & 10 & $\begin{array}{c}50 \% \text { defatted soya flour }+ \\
50 \% \text { soy peptides }\end{array}$ \\
\hline IV experimental group & 10 & 6 & $\begin{array}{c}50 \% \text { defatted soya flour }+ \\
50 \% \text { bees pollen pellet }\end{array}$ & 10 & $\begin{array}{l}50 \% \text { defatted soya flour }+ \\
50 \% \text { bees pollen pellet }\end{array}$ \\
\hline
\end{tabular}

Protein feed was moistened with 50\% sugar syrup and filled in the honeycomb. According to the experimental scheme during the preparatory period the bee colonies of the experimental groups II, III and IV were fed a feed mixture in an amount of $25 \mathrm{~g}$ per day. According to the experimental scheme during the main period bee colonies were fed a feed mixture of $70 \mathrm{~g}$ per day.

Accounting of bees brood on the set dates was carried out at the expense of a grid frame every 12 days.

Commercial honey was determined by weighing after pumping from each bee colonies separately. Forage honey was determined by weighing the honeycomb and then subtracting the conditional mass of the honeycomb.
Determination of wax production by bee families was carried out by weighing the melted honeycomb capping wax from each bee colony separately. Due to the wax production to the reconstruction of comb foundation is determined by counting the number of drawn out honeycombs from comb foundation given that bees produce $70 \mathrm{~g}$ of wax for each restored comb foundation frame of $435 \times 300 \mathrm{~mm}$.

\section{Results and discussion}

Experimental results on the effect of protein substitutes on the intensity of brood rearing showed different efficiency (Table. 2).

\section{Table 2}

For the experimental period the brood reared by bee families, $\mathrm{cm}^{2}$

\begin{tabular}{|c|c|c|c|c|c|c|c|c|c|}
\hline \multirow{2}{*}{$\begin{array}{l}\text { The bee colonies in } \\
\text { the experimental } \\
\text { groups }\end{array}$} & \multirow{2}{*}{$\begin{array}{l}\text { Number of bee } \\
\text { colonies in the } \\
\text { group }\end{array}$} & \multicolumn{8}{|c|}{ Average number of brood reared for the group on the following dates } \\
\hline & & 20.03 & 1.04 & 13.04 & 25.04 & 6.05 & 18.05 & 30.05 & $\begin{array}{c}\text { average for } \\
\text { reference period }\end{array}$ \\
\hline I control group & 10 & 1 & 1378 & 1010 & 20 & 3710 & & 5012 & 2995 \\
\hline $\begin{array}{l}\text { II experimental } \\
\text { group }\end{array}$ & 10 & $\begin{array}{c}1250 \pm \\
102\end{array}$ & $\begin{array}{c}1470 \pm \\
94\end{array}$ & $\begin{array}{c}1730 \pm \\
107\end{array}$ & $\begin{array}{c}2180 \pm \\
104\end{array}$ & $\begin{array}{c}3970 \pm \\
121\end{array}$ & $\begin{array}{c}5470 \pm \\
118\end{array}$ & $\begin{array}{c}5421 \pm \\
121\end{array}$ & 3213 \\
\hline $\begin{array}{l}\text { III experimental } \\
\text { group }\end{array}$ & 10 & $\begin{array}{c}1237 \pm \\
112\end{array}$ & $\begin{array}{c}1930 \pm \\
102\end{array}$ & $\begin{array}{c}2430 \pm \\
87\end{array}$ & $\begin{array}{c}2570 \pm \\
103\end{array}$ & $\begin{array}{c}4535 \pm \\
101\end{array}$ & $\begin{array}{c}6341 \pm \\
121\end{array}$ & $\begin{array}{c}7345 \pm \\
113\end{array}$ & 3769 \\
\hline $\begin{array}{l}\text { IV experimental } \\
\text { group }\end{array}$ & 10 & $\begin{array}{c}1261 \pm \\
112\end{array}$ & $\begin{array}{c}2070 \pm \\
105\end{array}$ & $\begin{array}{c}2560 \pm \\
108\end{array}$ & $\begin{array}{c}2950 \pm \\
97\end{array}$ & $\begin{array}{c}5170 \pm \\
117\end{array}$ & $\begin{array}{c}7250 \pm \\
111\end{array}$ & $\begin{array}{c}7932 \pm \\
118\end{array}$ & 4164 \\
\hline
\end{tabular}

In particular, it was found that in compared to their counterparts in the control group the bee colonies of the second, third and fourth experimental groups reared more brood on the first date by $6.5 \%, 40.0$ and $50.2 \%$,on the third date by $7.4 \%, 50.1$ and $57.0 \%$, on the fourth date by
$8.4 \%, 27.8$ and $46.7 \%$, on the fifth date by $7.0 \%, 22.2$ and $39.3 \%$, on the sixth date by $98 \%, 27.3$ and $44.8 \%$, on the seventh date by $6.8 \%, 22.1$ and $31.9 \%$.

The average for the experimental period, bee colonies of the second experimental group fed defatted soya flour reared 
of $7.2 \%$ more brood in compared to bee colonies of the control group. In compared to the control group when we used defatted soya flour and soy peptides for feeding bees of the third experimental group was observed to increase in brood rearing by $25.8 \%$ and for feeding defatted soya flour and flower pollen increased by $39.0 \%$.

Consequently, in the spring during the harvesting honey the bees are feeding with defatted soya flour and pollen that most contributed to the increase in brood rearing in comparison with feeding the bees of defatted soya flour and soy peptides and with feeding defatted soya flour.

Feeding bees with protein substitutes had a positive effect on their honey productivity (Table 3 ). Thus, the bee colonies of the second experimental group produced commercial and forage honey by 6.0 and $5.2 \%$, the third experimental group by 12.1 and $52.6 \%$ and the fourth experimental group by 21.2 and $57.8 \%$ more, in compared to their counterparts in the control group.

Table 3

Productivity of Honey Bee Colonies

\begin{tabular}{|c|c|c|c|c|}
\hline \multirow{2}{*}{$\begin{array}{c}\text { The experimental groups of } \\
\text { bee }\end{array}$} & \multirow{2}{*}{$\begin{array}{l}\text { Number of bee colonies } \\
\text { in the group }\end{array}$} & \multicolumn{3}{|c|}{ Honey production, $\mathrm{kg}$} \\
\hline & & commercial honey & forage honey & gross honey \\
\hline I control group & 10 & $16.5 \pm 1.4$ & $9.5 \pm 0.4$ & 26.0 \\
\hline II experimental group & 10 & $17.5 \pm 1.2$ & $9.0 \pm 0.7$ & 26.5 \\
\hline III experimental group & 10 & $18.5 \pm 1.3$ & $14.5 \pm 1.2$ & 33.0 \\
\hline IV experimental group & 10 & $20.0 \pm 1.0$ & $15.0 \pm 1.4$ & 35.0 \\
\hline
\end{tabular}

The bee colonies of II, III and IV experimental groups produced more gross honey by $19.0 \%, 26.9$ and $34.6 \%$ in compared to their counterparts in the control group.

Analyzing the beeswax productivity, it should be noted that the bee colonies of II, III and IV experimental groups produced more beeswax due to the honey comb capping by $2.4 \% 13.2$ and $16.5 \%$, and due to reconstruction of comb foundation by $21.4 \% 39.6$ and $38.2 \%$ in compared to their counterparts of the control group (Table 4).

Table 4

Wax productivity of bee colonies, on average of groups

\begin{tabular}{lcccc}
\hline \multirow{2}{*}{$\begin{array}{c}\text { The experimental groups } \\
\text { of bee }\end{array}$} & \multirow{2}{*}{\begin{tabular}{c} 
Number of bee \\
colonies in the \\
\cline { 3 - 5 }
\end{tabular}} & group & honey comb capping & reconstruction of comb \\
foundation & gross production \\
\hline I control group & 10 & $121 \pm 17$ & $280 \pm 12$ & 401 \\
II experimental group & 10 & $124 \pm 21$ & $340 \pm 17$ & 464 \\
III experimental group & 10 & $137 \pm 16$ & $391 \pm 15$ & 528 \\
IV experimental group & 10 & $141 \pm 11$ & $387 \pm 13$ & 528 \\
\hline
\end{tabular}

The gross beeswax production by bee colonies of II experimental group was higher by $15.7 \%$, the III - by 31.6 and the IV - by $31.9 \%$ in compared to the control group.

\section{Conclusions}

The use of combined protein feeds (defatted soya flour with soy peptone and pollen) for feeding bees in the spring during the harvesting honey has a positive effect on the brood rearing by bee colonies and the production of honey and wax in the following sequence: sequence: defatted soya flour and pollen $(50 \%+50 \%)$, defatted soya flour and soy peptides $(50 \%+50 \%)$, defatted soya flour $(100 \%)$.

\section{References}

Dobrovs'k, F. (2017). Pidgodivlja bdzhil syropom i cukrovodrizhdzhovym tistom. Bdzholjar, 8, 12-14 (in Ukrainian).

Drujbiak, A., Mironovich, A., Kovalska, L., \& Kovalskyi, Y. (2017). Pollen analysis included rectum of honey bees. Scientific Messenger of LNU of Veterinary Medicine and Biotechnologies. Series: Agricultural Sciences, 19(79), 135139. Retrieved from https://nvlvet.com.ua/index.php/ agriculture/article/view/2795.

Fedoruk, R. S., \& Romaniv, L. I. (2013). Reproduktyvna zdatnist' bdzholynyh matok za umov pidgodivli bdzhil boroshnom z bobiv soi' natyvnogo ta transgennogo sortiv. Biologija tvaryn, 15(3), 140-149 (in Ukrainian).
Gucol, A., Kovalskyi, Y., Kovalska, L., \& Gucol, N. (2017). Effect of probiotics on growth, development and economically useful traits honeybees. Scientific Messenger of LNU of Veterinary Medicine and Biotechnologies. Series: Agricultural Sciences, 19(74), 235-238. Retrieved from https://nvlvet.com.ua/ index.php/agriculture/article/view/2335.

Jagich, G., \& Losjev, O. (2020). Analiz vmistu trutnevogo gomogenatu zalezhno vid intensyvnosti rostu lychynok $u$ stil'nykah riznoi' generacii'. Tvarynnyctvo Ukrai'ny, 1, 16-23 (in Ukrainian)

Jefimenko, T. (2018). Prychyny otrujennja bdzhil pestycydamy. Pasichnyk, 8, 18 (in Ukrainian).

Komisar, O. D. (2005). Perga - novyj produkt bdzhil'nyctva. Pasika, 7, 8-9 (in Ukrainian).

Kosicyn, N. V. (2010). Lesnoe zakonodatel'stvo v organizacii pchelovodstva. Pchelovodstvo: nauchno proizvodstvennyj zhurnal, 9, 46-49 (in Russian).

Kosicyn, N. V. (2012). Ocenka medonosnyh resursov po dannym gosudarstvennoj inventarizacii lesov. Pchelovodstvo: nauchnoproizvodstvennyj zhurnal, 10, 18-20 (in Russian).

Kovalchuk, I., Dvylyuk, I., Lecyk, Y., Dvylyuk, I., \& Gutyj, B. (2019). Physiological relationship between content of certain microelements in the tissues of different anatomic sections of the organism of honey bees exposed to citrates of argentum and cuprum. Regulatory Mechanisms in Biosystems, 10(2), 177181. doi: 10.15421/021926.

Kovalskyi, Yu., Gucol, A., Gutyj, B., Sobolev, O., Kovalska, L., \& Mironovych, A. (2018). Features of histolism and hystogenesis in the vital temperature range in the organism of honey bee 
(Apis mellifera L.) in the postembrional period. Ukrainian Journal of Ecology, 8(2), 301-307. doi: 10.15421/2018_342.

Lazarjeva, L. M., Postojenko, V. O., \& Shtangret, L. M. (2017). Pylkovyj analiz medu z riznyh regioniv Ukrai'ny. Tvarynnyctvo Ukrai'ny, 3-4, 26-29 (in Ukrainian).

Polishhuk, V. P. (1975). Zbil'shennja vyrobnyctva produkcii' bdzhil'nyctva. Kyi'v. Urozhaj (in Ukrainian).

Polishhuk, V. P., \& Gajdar, V. A. (2008). Pasika. Kyi'v (in Ukrainian).

Ponomar'ova, E. G. (1980). Kormovaja baza pchelovodstva i opylenija sel'skohozjajstvennyh rastenij. Moskva. Kolos (in Russian).

Razanov, S. F., Bezpalyj, I. F., Bila, V. I., \& Donchenko, T. A. (2010). Tehnologija vyrobnyctva produkcii' bdzhil'nyctva. Kyi'v. Agrarna osvita (in Ukrainian).

Taranov, G. F. (1986). Korma i kormlenie pchel. Moskva. Rossel'hozizdat (in Russian).
Taranov, G. F. (1987). Promyshlennaja tehnologija poluchenija i pererabotki produktov pchelovodstva. Moskva. Agropromizdat (in Russian).

Verygin, I. (2010). Pryncypovo novyj metod pidgotovky bdzhil do zymy. Ukrai'ns'kyj pasichnyk, 8, 9-10 (in Ukrainian).

Vishchur, V. Y. Saranchuk, I. I., \& Gutyj, B. V. (2016). Fatty acid content of honeycombs depending on the level of technogenic loading on the environment. Visnyk of Dnipropetrovsk University. Biology, ecology, 24(1), 182-187. doi: 10.15421/011622.

Vishchur, V. Y., Gutyj, B. V., Nischemenko, N. P., Kushnir, I. M., Salata, V. Z., Tarasenko, L. O., Khimych, M. S., Kushnir, V. I., Kalyn, B. M., Magrelo, N. V., Boiko, P. K., Kolotnytskyy, V. A., Velesyk, T., Pundyak, T. O., \& Gubash, O. P. (2019). Effect of industry on the content of fatty acids in the tissues of the honey-bee head. Ukrainian Journal of Ecology, 9(3), 174-179. doi: 10.15421/2019 727 . 